
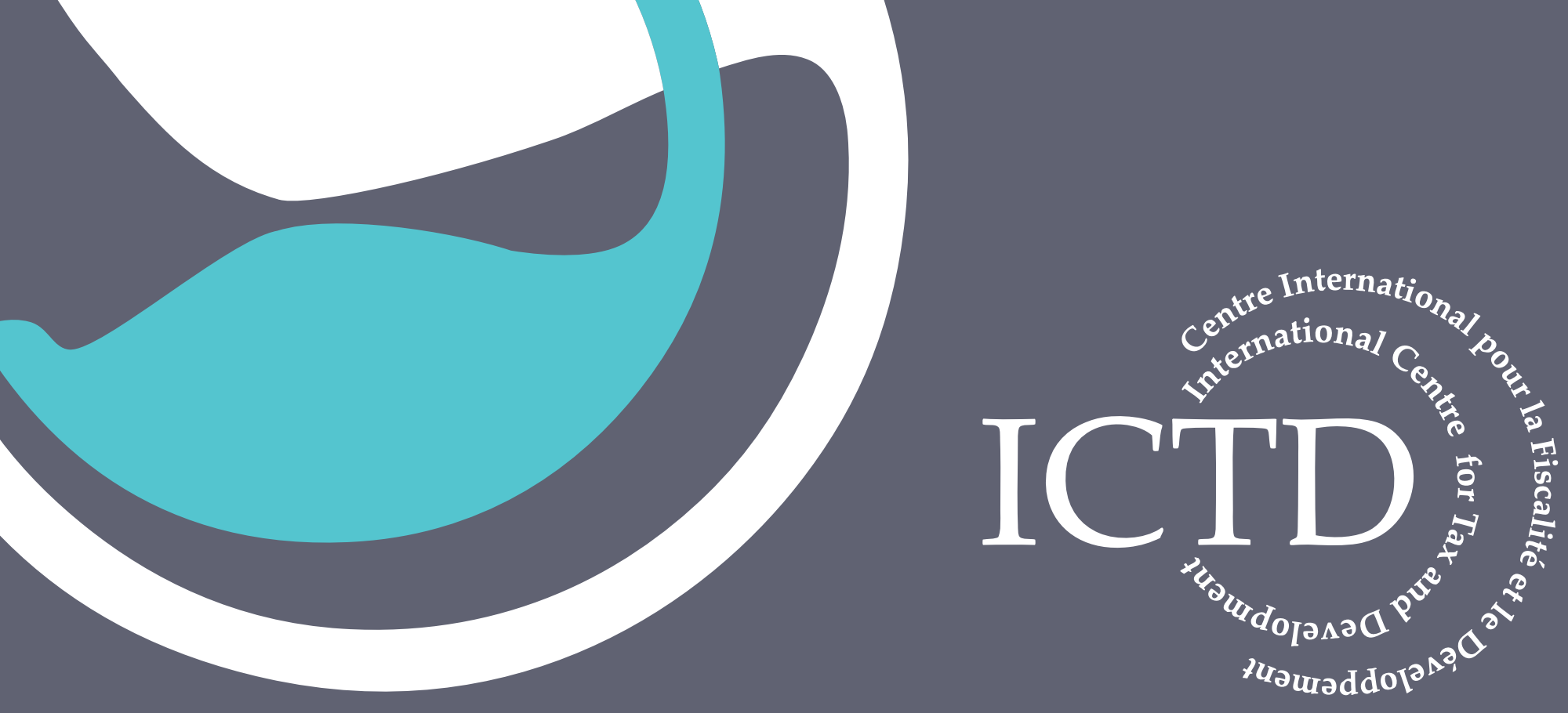

Working Paper 30

\title{
Norms, Power and the Socially Embedded Realities of Market Taxation in Northern Ghana
}

Wilson Prichard and Vanessa van den Boogaard

January 2015 
ICTD Working Paper 30

\section{Norms, Power and the Socially Embedded Realities of Market Taxation in Northern Ghana}

Wilson Prichard and Vanessa van den Boogaard

January 2014 
Norms, Power and the Socially Embedded Realities of Market Taxation in Northern Ghana

Wilson Prichard and Vanessa van den Boogaard

ICTD Working Paper 30

First published by the Institute of Development Studies in January 2015

(C) Institute of Development Studies 2015

ISBN: 978-1-78118-208-6

A catalogue record for this publication is available from the British Library.

All rights reserved. Reproduction, copy, transmission, or translation of any part of this publication may

be made only under the following conditions:

- with the prior permission of the publisher; or

- with a licence from the Copyright Licensing Agency Ltd., 90 Tottenham Court Road, London W1P 9HE, UK,

or from another national licensing agency; or

- under the terms set out below.

This publication is copyright, but may be reproduced by any method without fee for teaching or nonprofit purposes, but not for resale. Formal permission is required for all such uses, but normally will be granted immediately. For copying in any other circumstances, or for reuse in other publications, or for translation or adaptation, prior written permission must be obtained from the publisher and a fee may be payable.

Available from:

The International Centre for Tax and Development

at the Institute of Development Studies

Brighton BN1 9RE, UK

Tel: +44 (0) 1273606261 Fax: +44 (0) 1273621202

E-mail: info@ictd.ac.uk

Web: www.ictd/en/publications 


\title{
Norms, Power and the Socially Embedded Realities of Market Taxation in Northern Ghana
}

\author{
Wilson Prichard and Vanessa van den Boogaard
}

\section{Summary}

The advance of decentralisation efforts in Africa has brought with it expanded discussion of local government taxation, and the potential for tax reform to spur broader state building and governance gains. However, while this literature has acknowledged the importance of local politics and context, it has remained largely grounded in a formal understanding of local tax systems, rather than an understanding of the often informal day-to-day realities of sub-national taxation. This paper correspondingly provides a ground level view of market and small business taxation in two local government areas in Ghana's disadvantaged northern region. Doing so reveals a system shaped by ingrained informal practices that are grounded in existing social relationships and collective norms. These informal practices sometimes foster greater equity and responsiveness than formal rules, but in other cases serve to reinforce existing inequalities. We conclude by arguing that existing approaches to reform are likely to be undermined by a failure to appreciate the socially embedded realities of local government taxation, and we propose possible reform strategies that 'work with the grain' of existing practices.

Key words: local government taxation; informality; Ghana

Wilson Prichard is a Joint Research Director at the International Centre for Tax and Development, and an Assistant Professor within the Department of Political Science and Munk School of Global Affairs at the University of Toronto.

Vanessa van den Boogaard is a doctoral student within the Department of Political Science at the University of Toronto. She was a Research Officer at the International Centre for Tax and Development from 2012 to 2014. 


\section{Contents}

Summary 3

Acknowledgements $\quad 5$

Acronyms $\quad 5$

Introduction $\quad 6$

$\begin{array}{lll}1 & \text { Literature review } & 8\end{array}$

2 Background: local revenue collection in Ghana $\quad 10$

$3 \quad$ Local government taxation in practice $\quad 11$

3.1 Capacity, resource and institutional constraints 13

3.2 Moral economy, power relations and the practice of local market taxation $\quad 14$

3.3 Market traders, market associations and the state 18

$4 \quad$ Formal rules, informal realities and policy implications 21

4.1 Engage and strengthen local market associations 21

4.2 Engage traditional authorities $\quad 22$

4.3 Empower local government authorities $\quad 22$

5 Conclusion 23

$\begin{array}{ll}\text { Appendix: interviews } & 24\end{array}$

$\begin{array}{ll}\text { References } & 27\end{array}$

Figures

Figure $1 \quad$ Grants and transfers as shares of total assembly revenue, 2011

Figure $2 \quad$ Average per capita internally generated funds, 2009-2011 11

Table

Table $1 \quad$ Comparison of key features of Yendi and Lawra 


\section{Acknowledgements}

The International Centre for Tax and Development provided funding for this research. We are grateful to Shandana Khan Mohmand and Giulia Mascagni for providing useful comments and feedback. We are also grateful to the Local Government Service Secretariat and the Ministry of Local Government and Rural Development, as well as Christian Aid Ghana - Rebecca Dottey in particular - for providing invaluable support during fieldwork.

\section{Acronyms}

CFS

GoG

GRA

LDA

YMA
Centre for the Future State Government of Ghana Ghana Revenue Agency Lawra District Assembly Yendi Municipal Assembly 


\section{Introduction}

It is now widely accepted that while decentralisation has the potential to improve government effectiveness and strengthen democratic processes in low-income countries, these goals have frequently not been achieved (Bahl and Bird 2008, Devarajan, Khemani and Shah 2009). The construction of effective sub-national tax and revenue systems has offered a particularly vivid illustration of these challenges: fiscal decentralisation has been recognised as critical to the broader efficiency and governance gains promised by decentralisation, but is a realm in which reform has been particularly ineffective or, at the very least, incompletely administered (Jibao and Prichard 2013; Bird 2011). Explanations for these failures have increasingly focused on political barriers to reform, and on the importance of context-specific responses, thus moving beyond the largely technocratic approaches of the past (Smoke 2013; Jibao and Prichard 2013; Bahl and Bird 2008). However, most accounts have continued to begin implicitly with an image of an 'ideal', rational-legal system of local government taxation, whereas the reality of subnational taxation - particularly outside of major metropolitan centres - is often much 'messier' and characterised by pervasive informality, grounded in existing social relationships and collective norms. Existing reform prescriptions for local government taxation seek in many ways to simply wish these challenges away, calling for improved monitoring, greater capacity and reduced discretion. By contrast, we suggest that more effective reform can likely be achieved by 'working with the grain' of local governance realities (Booth 2011a; Kelsall 2011), by seeking to design reform in a way that is consonant with inescapable capacity constraints and the broader social reality in which collection efforts are embedded.

Acknowledging this disconnect, we provide a ground-level view of the day-to-day realities of local government taxation in the context of a decentralisation agenda that has been prioritised by both international donors and the central government. We do so through a focused study of market taxation in two districts in Ghana's disadvantaged northern regions, Lawra and Yendi. ${ }^{1}$ We focus on market taxation because it offers a lens into face-to-face interactions between relatively marginalised citizens - poor market traders, most of whom are women - and the local state. Aside from their relative fiscal significance to local assemblies, market taxes are important as they are often the principal manner through which traders interact with local government representatives (Owusu and Lund 2004). More basically, as a direct tax, market taxes are highly 'visible' to citizens, making them potentially more likely than indirect taxes to spur citizen engagement with tax bargaining and governance processes (Prichard 2010; Joshi, Prichard and Heady 2012; Bird and Zolt 2005). Moreover, through our focus on a relatively marginalised region of the country, we capture the reality of local tax institutions outside of major urban centres in two economically and politically distinct locations. Our goal is to reveal the informal norms and institutions governing the tax system as it functions in practice, and to explore the potential implications for local livelihoods and governance, and for thinking about local government tax reform.

In adopting this focus we draw on a rapidly growing literature focusing on the informal institutions and practices that often underpin local economies and governance systems. These

\footnotetext{
Ghana's northern regions have been relatively marginalised since before the colonial period, when Ashanti and Fante armies raided the northern areas for slaves for the transatlantic slave trade and later for the development of cocoa plantations in southern Ghana. This marginalisation continued during the colonial era, when educational and economic opportunities centred in the south, and persisted after independence. Within the last two decades, the gap between levels of development and per capita incomes in the north and the south has widened considerably, with recent economic development concentrated almost exclusively in the south (World Bank 2004).
} 
approaches seek to understand how these institutions interact with formal regulatory systems and practices, and how formal and informal processes can work together as 'hybrid' institutions, forming 'second best' approaches to governance (Meagher and Lindell 2013; Kelsall 2011; Centre for the Future State (CFS) 2010; Joshi and Ayee 2008; Guha-Khasnobis et al. 2006; Cleaver 2001; Titeca and Flynn 2014). However, while this growing body of literature has advanced thinking about 'real' governance in low-income countries, studies to date have generally focused on informality within cross-border trade or urban centres. By contrast, there are, to our knowledge, no in-depth studies of the day-to-day experiences of taxpayers in smaller towns - despite the fact these areas are home to a large share of citizens in low-income countries. We thus seek to shed light on an area that has been particularly overlooked by researchers, national policymakers and central tax administrations.

In order to do so, we draw on two months of intensive field research carried out in Lawra and Yendi in 2011 and 2012, as well as broader research about the Ghanaian tax systems spanning almost a decade. The field research included interviews and focus group discussions with market traders, representatives of various market associations and 'commodity groups', and indepth interviews with representatives from the respective local governments and central government ministries. This included semi-structured interviews with fifty traders in each location based on purposive selection from multiple 'commodity lines', as well as over fifty in-depth interviews with market representatives and government officials. ${ }^{2}$

We find that local tax systems are defined by a stark lack of administrative capacity, and the corresponding prevalence of informal practices. However, despite the absence of strong formal rules these informal practices are relatively predictable, accepted and ingrained, with day-to-day outcomes heavily shaped by existing communal and social relationships and collective norms. In many cases these ingrained informal practices improve equity and state-society relations, by, for example, smoothing tax demands in the face of seasonality and building trust between taxpayers and tax collectors. However, in other cases, they serve to reinforce existing social hierarchies and power relations, as with the exploitation of itinerant and foreign traders, or special privileges granted to well-connected individuals. Ultimately, we conclude that improved reform outcomes can be achieved by 'working with the grain' of these inescapable local realities, while seeking to minimise the potential costs of informality. In particular we stress the potential benefits of strengthening local market associations, engaging traditional authorities and empowering local tax authorities.

The paper proceeds in five parts. Section 1 reviews existing research that considers the day-today realities and informal institutions shaping local economic and governance structures in subSaharan Africa. Section 2 provides a brief background to the local government and tax system in Ghana. Section 3 provides a detailed description of the functioning of the local government tax systems in Yendi and Lawra, as seen by small business taxpayers and tax officials. The emphasis is on capturing not only the formal structure of the system, but the more informal realities of administration and of citizen engagement with the system. Section 4 explores potential strategies for pursuing reform in a way that better fits local institutional and social realities. Section 5 concludes.

See Appendix for a detailed list of interviews. 'Commodity lines' refer to the common organisational market structure wherein separate commodities or sets of commodities are concentrated in distinct retail areas (Clark 2010b). 


\section{Literature review}

Since the 1980s, decentralisation has been a central component of orthodox development policy agendas throughout sub-Saharan Africa. This policy push, largely driven by external actors, is based on the idea that by bringing the delivery of government services closer to the people, and by deepening democratic channels, decentralisation provides the key to better governance at sub-national levels. Despite widespread international support for decentralisation initiatives, however, recent evidence suggests that the assumed benefits of decentralisation are highly variable, with local revenue mobilisation, public service delivery and government accountability remaining weak within most decentralised governments in sub-Saharan Africa (Burki, Perry and Dillinger 1999; Booth 2011b; Bahl 1999; Grindle 2002; Jibao and Prichard 2013).

Poor governance outcomes in practice reflect, at least in part, the disconnect that exists between official policies and the often informal local institutional realities that shape outcomes in practice (Smoke and Lewis 1996). International policymakers have tended to frame decentralisation reforms through a paradigmatic Weberian lens that reflects recent Western institutional history, while focusing on narrow bureaucratic adjustments to formal institutions. As Booth (2011a: 2) explains, the orthodox good governance and institution building agenda 'fails to reflect the more genuinely universal experience that institutions work better when they build on what exists, make use of indigenous institutional creativity or are otherwise rooted in their sociocultural context'. This approach risks overlooking the many ways in which local political and social dynamics shape governance outcomes (Smoke 2013; Crook and Sverrisson 2003; Crook and Manor 1998; Crook 2003; Devarajan, Khemani and Shah 2009; Booth 2011a). Rather than simply a technical or managerial exercise, historical and social institutions shape decentralisation processes, defining practical, 'working' norms (Olivier de Sardan 2008).

Instead of being 'sidelined or viewed merely as barriers to changes whose desirability has been defined a priori' (Booth 2011a: 2), a more realistic assessment of the informal realities of subnational tax systems can shed light on how institutional resources and historical legacies might be positively harnessed to support local development - effectively, how policies can be designed to work 'with the grain' of existing social and governance structures (Booth 2011a; see also Kelsall 2011). Increasingly, informal economic and governance systems are seen less as 'backward' or 'dysfunctional', and more as 'arrangements that work' (Kelsall 2011). They are viewed as mechanisms that can be harnessed towards improving public service delivery, tax collection and governance through collaborative interaction between formal and informal institutions, described variously as 'hybrid governance', 'coproduction', and 'formal-informal linkages' (CFS 2010; Joshi and Moore 2004; Guha-Khasnobis et al. 2006; Meagher and Lindell 2013).

The importance of exploring 'real' governance at the local government level is thus increasingly accepted, though the implications of these systems for livelihoods and reform are invariably complex (Olivier de Sardan 2008). Recent research has captured the ways in which informal norms and institutions continually interact with official rules to generate the dynamic 'practical' norms that define the system of taxation experienced by taxpayers (Cantens 2012; Olivier de Sardan 2008; Blundo 2006; Titeca and de Herdt 2010; Titeca and Kimanuka 2012). In certain instances, these practical norms can address concerns that are ignored by state regulations, forming the basis of an underlying 'moral economy' motivated by popular norms of fairness and reciprocity (Thompson 1971; Scott 1976). 
However, alongside the potential benefits of informality lies the reality that informal governance practices are likely to reflect existing social hierarchies and power relations, and 'may demonise or exclude certain categories of people' (Cleaver et al. 2013; Meagher and Lindell 2013). Norm creation is a dynamic and continually negotiated process, dependent on the 'specific configuration of power that sustains the modus vivendi of different social actors in a specific domain' (Titeca and de Herdt 2010: 579; see also Olivier de Sardan 2008; Blundo 2006). Hybrid or plural governance arrangements may thus not create more inclusive economic or governance institutions in practice, but may instead simply increase opportunities for some while multiplying disadvantages for others (Cleaver et al. 2013).

These tensions are made plain by a small body of research that has begun to look at the informal realities governing taxation, primarily in post-conflict settings. Titeca and de Herdt (2010), for example, have argued that while non-statutory negotiation of tax rates may deprive the state of resources, it can equally respond to the realities of economic underdevelopment and political marginalisation. More broadly, in contexts where the state is weak and/or taxpayers are well-organised, informal practices can result in better treatment for taxpayers, including some circumstances wherein populations essentially dictate what taxes are extracted (Titeca and de Herdt 2010; Titeca and Kimanuka 2012).

However, in the majority of cases explored by recent research, the scope for coercion by government officials is substantial, while barriers to collective action by taxpayers are high, making small-scale and marginalised economic actors particularly unlikely to have power to influence the practical norms shaping the de facto rules of the game (Schomerus and Titeca 2012; Titeca 2011; Titeca and de Herdt 2010; Titeca and Kimanuka 2012). ${ }^{3}$ In some cases unofficial tax exemptions have been used as a means of political or social inclusion or exclusion, for example by discriminating against 'out-groups' such as foreigners or migrants (e.g. Flynn 1997; Juul 2006; Schomerus and Titeca 2012; Titeca and Kimanuka 2012; Meagher 2013). More broadly, it is frequently the weakest actors who are vulnerable to extortion, while more powerful actors are able to collude with tax collectors to avoid taxes.

The bottom line from existing research is not that informal or hybrid governance is inherently positive or negative for those affected, as observed impacts are diverse and context specific. Instead, the message is more nuanced: tax outcomes in practice are substantially shaped by informal norms and practices, and any effort to understand local government taxation, or to consider the potential for reform, should begin from an understanding of these realities (Blundo 2006; Olivier de Sardan 2008). Critically, while these patterns of informal tax governance shape tax incidence and livelihoods, they may also shape the ability of taxpayers to engage with the state, and their perceptions of the state and its legitimacy. For this reason, understanding the informal realities shaping local government taxation may also be critical to understanding decentralised governance more broadly (Joshi et al. forthcoming). With these broad lessons, we aim to contribute to the literature by providing an in-depth case study of taxation in market trade in marginalised areas outside of metropolitan centres, while at the same time broadening the discussion of the implications of informality in terms of intellectual and policy approaches to local government taxation and decentralisation.

With regard to the informal practice of tax rate negotiation, several studies have demonstrated that information and power imbalances in the negotiation of informal tax rates can actually make the burdens of informal taxes be higher than their formal equivalents, with a disproportionately negative impact on small-scale traders (World Bank 2011). 


\section{Background: local revenue collection in Ghana}

On the surface, Ghana has implemented an ambitious decentralisation programme. Under the decentralisation programme initiated in 1998, the country is divided into six metropolitan assemblies, 56 municipal assemblies and 154 district assemblies, each of which is, in turn, comprised of town, area, urban and/or zonal councils. ${ }^{4}$ In principle these assemblies exercise significant political and fiscal autonomy, with each assembly responsible for setting rates of taxation for local government taxes within its jurisdiction, with the bulk of internally generated revenue coming from fees for trading in the market or exporting foodstuffs outside of the district, business licenses and the basic rate, a poll tax. The assembly is responsible for gazetting, publishing and making publicly available these tax rates, which are reviewed annually and codified within a fee fixing resolution. Salaried tax collectors, employees of the local government whose salaries are paid by the central government, and commission-based collectors, who typically receive 10 to 20 per cent commission on market tickets, collect local taxes. Additionally, districts may periodically, often on an annual basis, organise a 'district task force' to collect taxes on one or more specified days. These task forces, made up of assembly employees and/or students and volunteers, are intended to mobilise revenue, especially within markets, in order to assess revenue potential, as well as, more often than not, to meet imminent revenue targets.

Despite seemingly strong legislative foundations - and symptomatic of the limitations of the broader decentralisation agenda - local revenue mobilisation in Ghana is extremely weak, with local governments heavily dependent on donors and fiscal transfers from the central government (Figure 1). Poor local revenue collection reflects poor performance and limited capacity, but also limited revenue sources allocated to local governments, with local governments retaining authority over an incoherent and complex set of revenue instruments that offer low collection potential and high collection costs. In this context, market revenues, in the form of fees and stall rents, are of considerable importance for local governments - as they have been historically (Clark 2010a) - representing an average of 27 per cent and 24 per cent of local government tax revenue from 2001 to 2011 in Lawra and Yendi, respectively. Finally, the central government retains an important direct presence in individual districts: the national tax authority - the Ghana Revenue Agency (GRA) - maintains regional and/or district offices responsible for collecting centrally controlled income and value-added taxes, while districts are overseen by a presidentially-appointed District Chief Executive, and up to 30 per cent of assembly members in each district are also appointed by the President (GoG 1992).

Metropolitan assemblies are those representing populations above 250,000; municipal assemblies represent populations of between 95,000 and 250,000; while district assemblies represent populations above 75,000. As local government nomenclature is simply based on population size, we use the terms 'districts' as a generic term to refer to all assemblies. 
Figure 2 Grants and transfers as shares of total assembly revenue, 2011

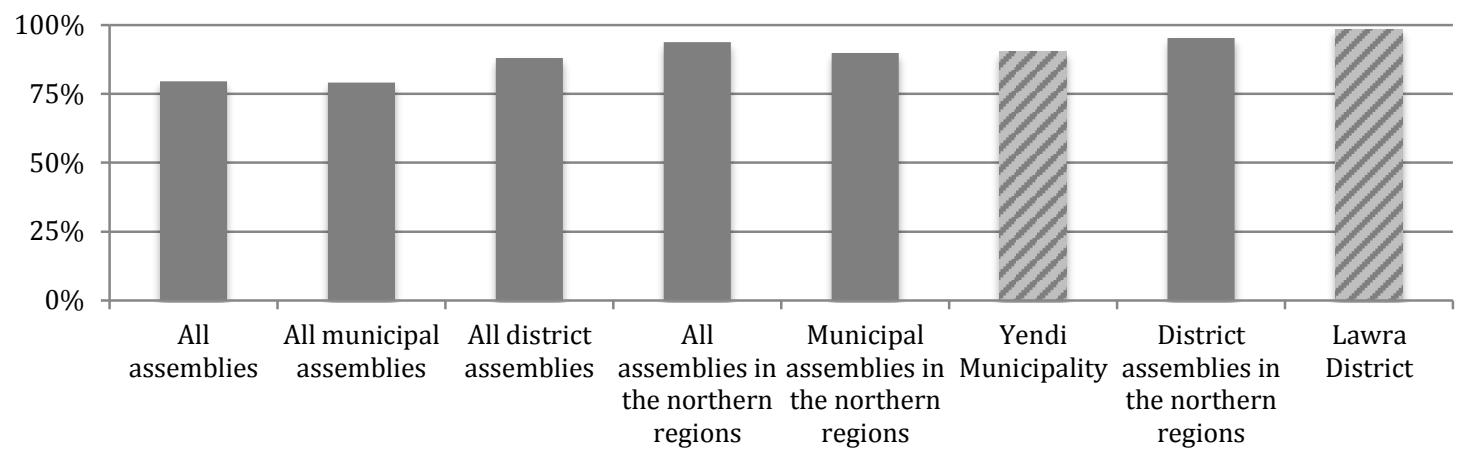

Note: 'The northern regions' refers to the Northern, Upper East and Upper West regions.

Source: Authors' calculations based on data from the Ministry of Local Government and Rural Development.

\section{Local government taxation in practice}

In order to capture the day-to-day realities of tax practice we focus on the districts of Yendi and Lawra in Ghana's marginalised northern regions. Both districts have primarily agricultural economies, with poverty rates far above national averages, while revenue collection on a per capita basis is comparable across the two locations, though below national averages for similarly sized districts (Figure 2). They thus offer insight into realities in comparatively marginalised regions, and among relatively marginalised groups.

Figure 2: Average per capita internally generated funds, 2009-2011

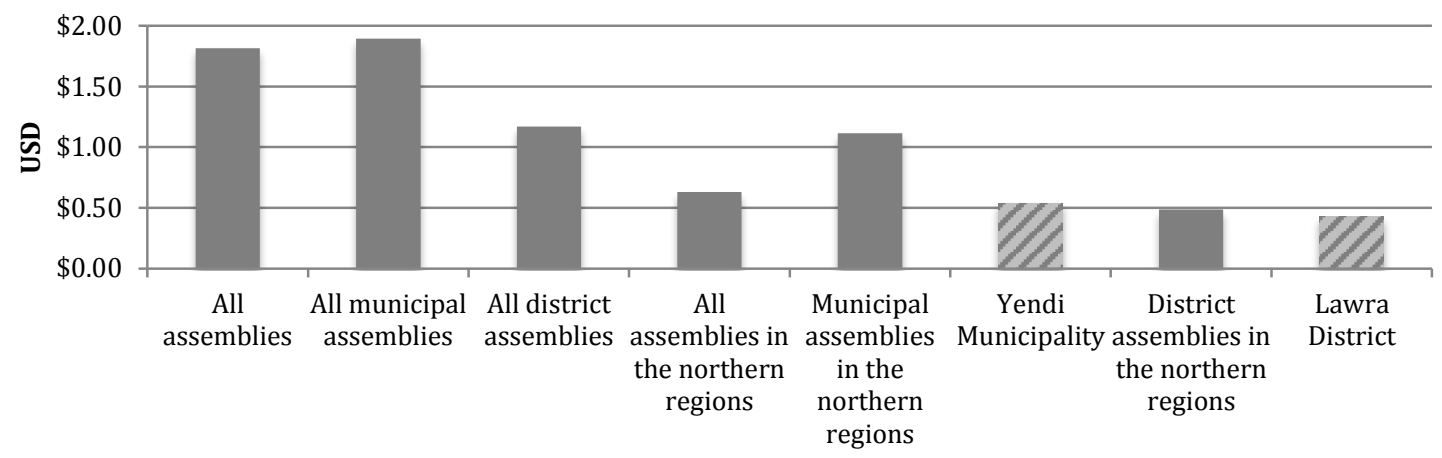

Note: 'Internally generated funds' include both tax revenue and other locally generated revenue, including that from investments. Data is based on the local government structure as it existed in 2011 and thus includes 124 districts, 40 municipalities and six metropolises. Per capita data is based on 2010 populations. USD equivalents are calculated using the international market exchange rate for 1 August 2012.

Source: Authors' calculations based on data from the Ministry of Local Government and Rural Development.

Though the goal is not to systematically compare the two districts, they also differ in important ways that allow for selective comparison and additional insights (see Table 1). Most obviously, Yendi is twice as large and more economically active, hosting larger daily and periodic markets, 
with more extensive permanent market infrastructure. More subtly, Yendi has been home to more adversarial politics in recent years, grounded in chieftaincy and ethnic conflict (Jönsson 2009). This has, in turn, been reflected in tax practices, with civil society leaders reporting relatively poor relations between taxpayers and the government in Yendi, as well as adversarial engagement by the chieftaincy with tax issues. ${ }^{5}$ By contrast, Lawra has been reported to exhibit much more positive attitudes toward tax compliance, and more positive engagement by the chieftaincy (Carroll 2011). We expect the latter to be associated with a greater degree of "quasivoluntary' or 'grudging' compliance - that is, a greater degree of taxpayer cooperation with tax authorities (Levi 1988; Moore 2013; Tilly 2005).

\section{Table 1: Comparison of key features of Yendi and Lawra}

\begin{tabular}{|l|l|l|}
\hline & Yendi Municipality & Lawra District \\
\hline Region & Northern & Upper West \\
\hline Population (2010) & 199,592 & $100,929^{6}$ \\
\hline Area & 5,350 square kilometres & 1,051 square kilometres \\
\hline $\begin{array}{l}\text { Average annual tax } \\
\text { revenue, 2001-2011 (USD) }\end{array}$ & $\$ 37,402.50$ & $\$ 18,686$ \\
\hline $\begin{array}{l}\text { Average annual per capita } \\
\text { tax revenue, 2001-2011 } \\
\text { (USD) }\end{array}$ & $\$ 0.19$ & $\$ 0.19$ \\
\hline $\begin{array}{l}\text { Permanent revenue } \\
\text { collectors }\end{array}$ & 4 & 0 \\
\hline $\begin{array}{l}\text { Commission-based } \\
\text { revenue collectors }\end{array}$ & 13 & 21 \\
\hline Daily market fees (USD) & $\$ 0.05$ & $\$ 0.05$ to \$0.15 \\
\hline Monthly market rents (USD) & $\$ 0.51$ to \$7.68 & $\$ 0.26$ to \$0.51 \\
\hline
\end{tabular}

Source: Authors' calculations based on data obtained from local assemblies.

Market interviewees in our case studies reflect a mix of small traders that operate exclusively within district markets, and traders that have additional operations outside of the market space itself in small business spaces or kiosks. Of the respondents, 98 per cent reported paying local taxes, though with variation between market fees, market rents and other taxes. Approximately 46 per cent reported paying exclusively daily market fees, 20 per cent paying monthly market rents for occupying formal market stalls, 31 per cent paying both market fees and market rents, and 3 per cent paying another type of local tax. Additionally, 58 per cent of interviewees regularly made some form of payment to a local traditional authority, while 9 per cent, all of whom operated small businesses in addition to their market trade, reported paying national income taxes in the form of 'tax stamps'.

$5 \quad$ Personal interviews with senior staff members from Christian Aid Ghana, the Ghana Integrity Initiative and the Ghana Association of Women Entrepreneurs, November 2011, Accra, Ghana. These organisations have all been involved with previous studies of tax practices in Lawra and Yendi, and these perceived differences between the two locations helped to inform our case selection.

$6 \quad$ In 2012, as part of a nationwide local government administrative reorganisation that created 46 new districts, Lawra District was split into two administrative districts: Lawra and Nandom. Accordingly, the 2010 population data reported is larger than the cut-off for district assemblies, though Lawra was still considered a district rather than a municipality.

$7 \quad$ At the national level firms in the informal sector are subject to a presumptive system of income taxation by which firms pay a quarterly flat rate tax based on their area of business and size, and in return receive a tax stamp for display at their place of business. 
Against this background, our analysis proceeds in three parts. First, we highlight key features of the economic and institutional context for local government market and small business taxation, highlighting a series of relatively inescapable constraints shaping tax collection. These resource and capacity constraints, in turn, serve to make informal practices an unavoidable, and pivotal, feature of tax collection in practice. The second part of the analysis correspondingly focuses on capturing these informal practices, highlighting the ways in which local economic realities, social norms of fairness and reciprocity, and social hierarchies and power dynamics influence outcomes. Finally, we consider the nature of relations between market traders, market associations and the state, highlighting continued barriers to strengthening the effective voice of marginalised taxpayers.

\subsection{Capacity, resource and institutional constraints}

Understanding the day-to-day realities of market and small business taxation requires first an appreciation of the stark capacity, resource and institutional constraints confronting tax collection efforts. As in low-income countries more generally, the tax system is hampered by human and resource capacity constraints, with revenue collectors and supervisors demonstrating limited procedural, technical or rights-based understanding of the local tax system. Rapid fiscal decentralisation has likewise created challenges in the establishment of functional bureaucratic institutions, particularly at the sub-district level; indeed, several sub-district councils and revenue offices in Yendi were not fully operational at the time of research as a result of resource constraints. ${ }^{8}$ These challenges are exacerbated by low wages for local revenue collectors, particularly relative to those of national collectors. These low wages were widely reported by both salaried collectors and collectors on commission as fuelling their lack of motivation, thus creating challenges for local governments to attract qualified individuals. Aside from low revenue potential from small traders, commission-based incomes are particularly vulnerable on account of seasonal fluctuations in market activity and irregular payment schedules.

Administrative fragmentation and weak monitoring of tax collectors, particularly in sub-district areas, exacerbates the issue of limited capacity. Neither Yendi nor Lawra set revenue targets for sub-district areas, while several revenue collection offices were simply not monitored at all, reflecting high monitoring costs and low revenue potential. Accordingly, district officers reported that area councils often fail to remit revenue to the assembly for periods of four to six months at a time. A lack of monitoring has, in turn, enabled illegitimate tax collectors to extract revenue with virtual impunity from market traders in certain cases. This is most notably true of itinerant traders travelling to the rotating periodic or central district markets, who often face double taxation - once in their home area, and a second time in the host market. Ultimately, the Yendi External Auditor, of the Ghana Audit Service, succinctly captured the weak state of monitoring, lamenting 'no one is taking responsibility for revenue raising in the districts'. 9

Finally, while fragmentation and weak monitoring open the door to informal practices, the potential for informality is amplified by unclear rules and unequal power dynamics. Most obviously, the complexity and opacity of local government taxation, and market taxation in particular, has consequences for equitable tax enforcement. Distinct market fees are charged for every conceivable commodity, generating a poor understanding of tax legislation among both

\footnotetext{
8 The number of assemblies has increased from 110 in 1988, to 138 in 2006, to 170 in 2008, to 216 in 2012 . Each assembly has lower levels of government (local, area and/or urban councils), implying significant institutional, human resource and financial needs. Personal interview with Yendi Municipal Assembly (YMA) Accounts Officer, December 2011, Yendi, Ghana. (GoG 1992: Art. 188). Personal interview with the Yendi External Auditor, July 2012.
} 
taxpayers and tax collectors, and ample space for arbitrariness and negotiation in the setting of rates. Meanwhile, weak local institutions and capacity provide significant scope for politically influential individuals to circumnavigate bureaucratic processes or pressure tax officials to lower or overlook their tax assessments, with negative implications for the uniform application of tax legislation and the horizontal equity of the tax regime. ${ }^{10}$

\subsection{Moral economy, power relations and the practice of local market taxation}

The formal institutional environment for tax collection is thus characterised by bureaucratic weakness and significant scope for discretion. The result, however, is not a simple proliferation of arbitrary enforcement and corruption. Instead, we find that outcomes 'in the shadow' of weak formal institutions are governed to a significant degree by socially embedded norms and informal practices that dictate relatively consistent divergence from formal policy. These informal practices may have positive implications for social welfare and horizontal equity, as they are driven by local economic realities and accepted notions of fairness. However, underlying power dynamics and social hierarchies equally shape informal norms in practice, limiting their equalising potential.

At a basic level, the official tax system may be too inflexible to be well suited to local economic realities, and this is reflected in the informal realities of enforcement. Government representatives generally assume that taxes and fees on the poorest segments of the population are so low as to have a negligible impact on taxpayers. However, while local market taxes may be modest in absolute terms, they often represent a significant and steady burden on highly variable, seasonal and insecure incomes. As Bahiigwa et al. (2004: 9) note, 'to say that the amounts involved are too small to really matter... is to distort the very meaning of poverty, which is that people's consumption is already below the minimum acceptable level'. The majority of the 100 traders interviewed for this study reported less than US\$5.10 in daily gross turnover. This implies regularly receiving little or no daily profit after accounting for the costs of trading and borrowing, as well as, perhaps more importantly, a very high degree of vulnerability in the face of seasonal fluctuations and unexpected shocks (Scott 1976: 156).

The rigid formal system is ill suited to deal with the variability and unpredictability inherent in precarious local economic realities. Front line officials correspondingly often adopt informal practices, driven by social norms of fairness, to soften the impact of blunt formal tax instruments. ${ }^{11}$ For instance, while local collectors are mandated to collect market fees daily, tax collectors in Lawra are reported to be 'sympathetic' to traders during the seasonal market downturn, collecting market fees less frequently during the rainy season. ${ }^{12}$ By understanding the reality that in a bad season a fixed tax applied with 'blind rigor' is in effect, 'an expanding proportional claim on... diminishing resources' (Scott 1976: 52 and 92), local tax collectors are able to make tax rates more sensitive to actual profits than is permitted by statutory rules. Moreover, in practice collectors apply relatively standardised informal exemptions for, most

Personal interview with Lawra District Coordinating Director, August 2012, Lawra, Ghana. Looking beyond market taxes, in our case districts this has resulted in the virtual non-collection of property tax, as well as certain inequities in the tax code itself: for instance, in Lawra, the bicycle and motorbike tax rates are more expensive than the rate for a private car (Lawra District Assembly (LDA) 2009).

11 Kinyanjui (2013: 150) describes such processes as the 'creation of an African indigenous social economic order' based on indigenous business norms, the 'wide use of social relations', and the application of 'African institutional values [...] such as sharing, reciprocity, loyalty, and altruism'.

12 Such unofficial practices of providing 'subsistence security' in the form of informal seasonal exemptions have been described as 'nearly universal in traditional society', though they have rarely been recorded (Scott 1976: 5-6, 54). This has generally been a pragmatic strategy on the part of authorities, as the inflexibility of the tax regime has recurrently been a source of tax resistance and, in extreme cases, class protest and rebellion (Scott 1976: 92). 
notably, the elderly, disabled, recently widowed, and mothers of young twins. ${ }^{13}$ For example, taxpayers and tax collectors in Yendi market relayed the example of an elderly trader who is no longer asked to pay tax, as collectors 'take pity on her' because she is 'tired', with collectors simply moving along to 'stronger women'.

The majority of traders support these informal exemptions, which thus represent socially sanctioned ways through which frontline officials enhance the progressiveness and legitimacy of the local tax system. Further, tax collectors in both districts described hesitancy to enforce penalties, which are fixed regardless of the tax rate in question, and can be as high as 50 times the original rate (LDA 2009). Local tax collectors were reported to be understanding to traders making little profit, allowing traders to make up for missed payments at future collections, taking goods in lieu of payment or simply ignoring tax obligations. Other traders generally do not perceive these forms of evasion negatively. For example, traders explained that in certain instances it may even be fair for other traders to hide from collectors, as these women may simply be trying to ensure that they have enough money to pay for their trips home and to feed their families.

Social norms of fairness also inform local understandings of acceptable forms of 'corruption'. While tax compliance theory suggests that corrupt tax collectors or uneven tax enforcement may lower tax morale by reducing perceptions of fairness (Cummings et al. 2005; Torgler 2005; Fjeldstad 2004; Fjeldstad and Semboja 2001), there was widespread acceptance by taxpayers of forms of petty corruption amongst tax collectors. Indeed, traders often explained that due to low commission rates, it is fair for collectors to keep a little extra for themselves or to "chop small'. ${ }^{14}$ As several female traders explained within the Lawra market, 'everyone eats at work.' This is not to say that all forms of 'corruption' were deemed acceptable: traders frequently condemned efforts to extract large sums from those who could not pay, or the tendency of some collectors to extract additional revenues from illiterate or foreign women, as discussed below. Instead, it is a further indication that practices in the market, and notions of what constitutes 'corruption', are socially embedded within local logics and norms (Olivier de Sardan 1999), implying a subjective and context-specific understanding of legality and legitimacy. This fundamentally implies that policy approaches must 'not begin with an abstract normative standard, but the values of the real actors' (Scott 1976: 160).

A general principle of reciprocity underlies these social norms (Scott 1976; Gouldner 1960; Olivier de Sardan 2008), reflecting what Roitman (2005: 89) describes as 'the logics of social exchange - the tightly spun web of rights, obligations, and sensibilities that are dramatised in transfer'. From one side, the chief revenue collectors in both districts explained that they are hesitant to enforce the relatively severe penalties for tax evasion, as their capacity to encourage tax compliance is underpinned by social relationships with taxpayers, and would be undermined by violating social norms of fairness. ${ }^{15}$ From the other side of the relationship, taxpayers described sympathy with collectors and a desire to pay whenever they are able, in order to help collectors avoid trouble with their supervisors. For instance, a woman selling beans without a stall in the Yendi market explained that if she pays her market fee, it leaves both her and the collector free to do their jobs. The willingness of collectors 'to go and come' is particularly valued

\footnotetext{
13 These types of informal tax exemptions have been recorded in other recent cases: for instance, in the African Great Lakes region, informal customs tax exemptions may be informally made for essential foodstuffs, pregnant women, the disabled, and other social categories deemed worthy of assistance (Titeca and Kimanauka 2012; Tegara and Johnson 2007).

14 'To chop' in Ghanaian English refers to all illegal modes of enrichment through positions of authority, similar to Francophone Africa's bouffer (Olivier de Sardan 1999: 28).

15 Personal interviews with YMA Chief Superintendent of Revenue Collection, December 2011 and July 2012, Yendi, Ghana and LDA Chief Market Revenue Collector, December 2011, Lawra, Ghana.
} 
by traders, given the unpredictability of their daily solvency, and was central to traders' feelings of solidarity and reciprocity with tax collectors. Meanwhile, in Lawra, where taxpayers are relieved of daily tax obligations during seasonal downturns, taxpayers showed an appreciation for local tax collectors and a willingness to pay in order to make collectors' jobs as easy as possible. Put most broadly, when taxpayers voluntarily comply with tax demands, there is tacit consensus that collectors will be more understanding to taxpayers when they are unable to pay.

Alongside these norms of reciprocity, tax compliance is shaped to a significant extent by broader social relations and expectations in the market. Taxpayers described a willingness to comply with tax payments in order to avoid disrupting the social order, to 'keep the peace' within the market, to avoid public embarrassment, and to maintain good relations with tax collectors, whom traders in Lawra described as the community's 'brothers' and 'sons'. ${ }^{16}$ This is consistent with what Clark (2002, 2010b) describes as the 'need to keep trade running smoothly' - a collective desire within the market and one that ensures compliance with informal agreements and norms. However, it is important to note that social influences and economic motives are closely intertwined. While the social costs of challenging social expectations may be high for traders, traders in both Lawra and Yendi equally explained that being labelled disruptive and 'anti-social' by other traders also carries important economic costs. ${ }^{17}$

A comparison of taxpayer perspectives about national and local tax collectors offers a further window into the particular role that norms of fairness, social obligation and reciprocity play in local government market taxation. Within our case districts, taxpayers made clear distinctions between tax collectors from their communities and national collectors. The latter are often from different regions and ethnic backgrounds and are more likely to be perceived as 'strangers', not fitting within local reciprocal networks and notions of exchange and solidarity. ${ }^{18}$ Traders perceive local tax collectors to be more responsive to local economic and social realities, whereas national tax collectors are seen to represent an inflexible application of tax legislation, providing less opportunity for informal tax settlements, little leniency with regard to non-payment and a stricter application of penalties (see also Atuguba 2006). For instance, reflecting a common experience amongst traders, a batik seller in Yendi described having no issues with local collectors, but described GRA collectors as being less understanding, unfriendly, 'harsh' and 'quarrelsome', and more willing to lock her store or confiscate her goods than the local collectors. Unsurprisingly, taxpayers in both case districts reported less willingness to pay taxes to national collectors.

A final component of these informal norms and practices is the enduring role of the chieftaincy in tax collection. ${ }^{19}$ Though indirect involvement by chiefs in tax collection is not mandated by

16

Seventy-four per cent of traders explained that they pay taxes because there is no alternative if they want to trade in the market and 'keep the peace'. Indeed, traders in Lawra market described their willingness to pay tax in order to avoid the 'penalty' of having collectors 'not being happy with them' or having collectors embarrass them in front of their peers. In Yendi market, some traders highlighted that an informal penalty of not paying the market tax is related to being perceived by other traders as disruptive and 'anti-social'. They accordingly explained that they pay tax in order to avoid public humiliation. This is corroborated by other research; for instance, Olken and Sighal's 2011 cross-country study of community-based informal tax systems finds that compliance is enforced by systems of social sanctions, such as peer pressure, public shaming, or community ostracism. As explained by Olivier de Sardan (1999: 46): "Shame" is, in the majority of African cultures, a powerful means of social control'.

17 Cleaver et al. (2013) describe such economic costs in terms of 'loss of reputation, goodwill and patronage, payment of fines, time spent resolving disputes, and restricted [...] access' to public goods.

18 Indeed, the GRA has a policy of frequently transferring staff to different districts in order to avoid familiarity between tax collectors and taxpayers. Personal interview with senior district GRA official, December 2011, Yendi, Ghana.

19 As a part of indirect rule, chiefs were charged and remunerated for collecting taxes and tributes on behalf of the colonial government (Jönsson 2009; Atuguba 2006; Agyemang 2011; Rathbone 1999), though a legitimate taxing authority, materialising in different manners, extends much further back for chiefly communities in the south and the centralised, chiefly communities of the northern regions (Atuguba 2006; Ladouceur 1979; Tait 1961). 
legislation, and direct taxation on their part is constitutionally barred (GoG 1992: Art. 174.1), local governments' capacities to extract revenues often remain dependent on the unofficial involvement of traditional authorities. At the same time, direct collection of informal 'taxes' by chiefs remains common, for instance, to provide for seasonal harvest festivals or communitybased projects (see also Agyemang 2011; Atuguba 2006; Jönsson 2009; Rathbone 1999). These taxes are based, in principle, on a reciprocal relationship with taxpayers: chiefs receive taxes in cash and kind, while taxpayers can then come to them to address disputes or to receive forms of social insurance in downtimes (Atuguba 2006). Meanwhile, chiefs' influence over formal tax compliance is rooted in their ability to shape popular perceptions of the legitimacy of local taxes, and of local governments more generally.

In both of our cases, support for formal local government tax collection, or lack thereof, can often be understood as part of a broader struggle for local-level influence. In Lawra, the chieftaincy has played an important role in public forums and in tax education and sensitisation campaigns, thus generally supporting tax collection. ${ }^{20}$ By contrast, efforts to undermine tax collection are reportedly much more prevalent in Yendi. Recent intra-chieftaincy conflicts have negatively affected the relationships between the local government and chiefs, with corresponding consequences for the willingness of the chiefs to support local government revenue-raising efforts. Indeed, during the localised conflict in Yendi in the early 2000s and for many subsequent years, the local government faced major challenges in collecting local revenues on account of disharmonious relations between the chiefs and the local government. ${ }^{21}$ In other instances, 'social insurance' from chiefs has come in the form of shielding taxpayers from local or national government collectors. The prominent role of chiefs, despite the absence of any legal standing in this domain, serves as a further illustration of the importance of informal norms in shaping tax practices, and of the ways in which informal norms can serve to increase equity by 'shielding' taxpayers from what are perceived to be unfair, or unrequited, extractions.

However, while the informal norms and practices discussed so far may reflect a local moral and social economic order, the story is not uniquely positive. Just as informal norms and practices can improve outcomes and yield greater cooperation, such informal norms and practices can equally legitimise and reinforce existing inequities, as these informal practices are rooted in power dynamics and social hierarchies (Roitman 2005; Cleaver et al. 2013; Titeca and de Herdt 2010; Titeca and Kimanuka 2012). In our case districts, the most vulnerable groups in the market - including illiterate, itinerant, and foreign traders - were widely felt to receive less favourable treatment by tax collectors. For instance, traders accused local tax collectors, particularly at the sub-district level, of taking advantage of illiterate and non-Ghanaian traders by charging them twice using the same tax receipt, charging higher rates than listed on the receipt or giving them counterfeit tax receipts. ${ }^{22}$ In other instances, application of social norms is uneven, based on the power and discretion of the tax collector. For instance, while habitual exemptions were made in Lawra for a pito brewer whose business was slow, kayakaya (market porters) and women selling small amounts of vegetables did not receive the same benefits, even

20

Personal interviews with LDA Finance and Budget Officers, December 2011 and August 2011, Lawra, Ghana; Christian Aid Ghana Country Manager and Programme Officer, November and December 2011, Accra, Ghana; and Ghana Integrity Initiative Programme Manager, November 2011, Accra, Ghana.

21 Personal interviews with YMA Municipal Finance Officer and Deputy Municipal Finance Officer, July 2012, Yendi, Ghana. This has historical precedence more broadly: indeed, when Nkrumah's post-independence government reduced the political autonomy and authority of traditional authorities beginning in the late 1950s, chiefs opted not to cooperate with local councils, resulting in significantly decreased tax revenues (Agyemang 2011).

22 At the same time, itinerant and foreign traders in Lawra may pay the market fee at a greater frequency than daily resident
traders as they are made to pay the tax every time they visit. While not all itinerant traders attend sub-district area council traders as they are made to pay the tax every time they visit. While not all itinerant
markets daily, those that do may end up paying more frequently than local traders. 
though their profits were felt to be comparable. Instead, these traders often had to borrow money from peers in order to pay the market fee.

In other cases, certain individuals enjoy informal privileges in the market, putting others at competitive disadvantages. Perhaps the most extreme example comes from the fact that larger traders renting formal market stalls are often not required to pay daily market fees in practice, making their cumulative monthly tax payments less than those of smaller traders who are required to pay a daily market fee. In other cases, politically connected traders, relations of the local chiefs and relations of tax collectors are often informally exempted from market fees, while relations of the chief and the traditional landowning class enjoy other market privileges, including the right to take goods from traders at no cost. One might expect there to be a less positive view of unofficial exemptions from local taxes for the extended family of the traditional landowning class, however the majority of traders simply accepted this practice as a fact of their social system.

The aggregate impact of these various informal practices is difficult to gauge precisely. Nevertheless, survey evidence from Carroll (2011) indicates that the overall effect may be regressive, even when compared to an already regressive formal system. This is consistent with our findings: those in privileged positions appear to benefit most from special treatment, while informality often increases the vulnerability of those with the very lowest incomes (itinerant traders, illiterate traders). On the other hand, for the bulk of market traders there are also substantial benefits arising from greater flexibility, attention to the effects of seasonality and special treatment for the elderly, disabled and widowed. That is, the reality is consistent neither with a romanticised view of a purely moral informal economy, nor with a legalistic approach that labels all form of informality corruption. In any case, the question of ultimate interest is not whether informality is, on balance, 'good' or 'bad'. As the discussion so far makes clear, informality is in many ways an inescapable feature of local government taxation of market traders and small businesses. The more relevant question, to which we return later, is how to align reform strategies with the reality of these systems as they function in practice.

\subsection{Market traders, market associations and the state}

While an understanding of the day-to-day realities of market taxation offers insight into the incidence of taxation and the broader forces shaping tax collection, it also offers a lens through which to consider broader questions about the relationship between small taxpayers and the state. A growing literature has argued that a critical motivation for more effective market taxation lies not in the (very modest) revenue collected, but in the potential for tax collection to act as a catalyst for more active engagement between market traders and the state, thus potentially spurring the expansion of accountability (Joshi et al. forthcoming). However, there is mounting recognition that such 'tax bargaining' is far from guaranteed: despite some localised evidence of mobilisation by small business associations, there are stark barriers to effective collective action by the marginalised groups, as these groups frequently confront unresponsive governments and weak and internally undemocratic market associations (Joshi and Ayee 2008; Prichard 2010; Meagher and Lindell 2013). There is a corresponding need to better understand the barriers to effective collective action by market associations, and potential areas of opportunity.

The challenges to collective action are readily apparent in our case districts, where traders tend to be poorly organised and to demonstrate little understanding of the local tax system. Within our case districts, less than a fifth of all respondents (17 per cent) reported knowing how their assembly spends tax revenues, while what was 'known' was often inaccurate. For instance, the vast majority described local tax revenues being used for community development projects, such 
as schools and roads, which are in fact funded by central government transfers or external grants; whereas almost all locally generated revenues fund the administrative costs of the assemblies. The majority of traders in both case districts reported never having engaged with tax collectors or assembly representatives to discuss issues of taxation, never having attended a civic education programme on taxation, and feeling like they do not have the right to ask questions of collectors or assembly representatives. A majority (60 per cent) of respondents did not feel well informed about why they pay taxes, though this number was 80 per cent in Yendi, and only 36 per cent in Lawra. Better information in Lawra is consistent with the potential for markets to be sites for spreading information and engagement, as Lawra is home to a larger range of market associations and closer ties between tax collectors and taxpayers.

While the potential for market associations to act as conduits for information is thus apparent, so too are the limits of the reach of these associations. None of the traders interviewed in Yendi were members of any association or cooperative. While 34 per cent of respondents in Lawra reported involvement in associations, the majority were described as susu (Akan for 'small small') organisations or rotating savings and credit associations, rather than vehicles for political mobilisation or engagement. ${ }^{23}$ While membership of 'formal' associations is limited, markets throughout Ghana are also informally organised into a system of commodity-based groups (Clark 1991, 2002, 2004, 2010a and 2010b). These groups may have a formal structure with officially recognised members, but may also be more informally defined (Clark 1991, 2004). These informal organisations are designed to offer mutual support for traders, including support in negotiating with government officials and chiefs, while they equally serve to reinforce informal rules and sanctions within the market (Clark 2010a, 2010b).

However, despite the well-established role of these informal organisations in Ghanaian markets, traders in both districts reported a lack of accountability on the part of association leaders. While research by Clark (1991, 2010a, 2010b) has pointed to the existence of informally institutionalised forms of internal and external accountability within commodity groups elsewhere in Ghana, our evidence reinforces the message that effective accountability is not universal or guaranteed - even in Lawra, which has been identified by other researchers as an example of relatively inclusive market governance around taxation (Carroll 2011, author interviews) ${ }^{24}$ Consistent with research elsewhere, we find that market associations often lack inclusivity and internal accountability, while sometimes exacerbating social divisions and economic exclusion owing to inequitable patterns of inclusion (Joshi et al. forthcoming; Meager 2010 and 2013; Booth 2011a). Traders described associations as being dominated by politics amongst traders and leaders, with some associations being dissolved for internal 'political' reasons.

We similarly do not find evidence in our case districts of associations or commodity groups serving as effective links to the local government (see also Owusu and Lund 2004). Indeed, traders reported that the association leaders, or 'market heads', had no clear channels of access to the assembly, while traders did not perceive them as direct routes to information or accountability. This is more apparent in Yendi, where the Yendi Cooperative Food and Farming Market Society, the primary market association, has a limited number of members, with unclear information diffusion strategies within the market and unclear representation, despite having an

\footnotetext{
23 A distinction should be drawn between Western and indigenous ideas of 'organisation'. Clark (2010b: 250) emphasises that 'Western models of cooperatives, with committees and secretaries, supplement but do not supplant' existing forms of organisation, such as those based on chieftaincy models. Indeed, she notes that traders may adopt the trappings of Western models of market organisations in order to access new forms of legitimacy, effectively 'incorporating Western terms and institutions into indigenous patterns... without disrupting them substantially' (Clark 2010b: 258-9). Personal interviews with senior staff members from Christian Aid Ghana and the Ghana Integrity Initiative, November 2011, Accra, Ghana.
} 
assembly member on its committee. ${ }^{25}$ These connections are somewhat stronger in Lawra, which is home to a larger number of formal associations as well as direct communication channels to the district assembly through the Lawra District Union, which represents 16 cooperatives and 300 members across the district. However, even the union's executive secretary explained that these communication channels offer limited substantive engagement with the assembly and are largely ineffective in practice, while taxpayers complain that they often do not receive even basic tax information through the associations. ${ }^{26}$

The weakness of links between taxpayers, market associations and the government is most clearly illustrated by the process for approving the annual fee fixing resolution, which sets local tax rates. In both districts, assembly finance officials described the process as being fair and inclusive, with representatives of market associations both contributing to policy formulation and communicating the fee fixing resolution to their members. However, the Yendi External Auditor, of the Ghana Audit Service, explained unequivocally that the resolution is, in fact, set without consultation with the market traders or their associational representatives, while the same situation was reported in Lawra. ${ }^{27}$ Meanwhile, traders and tax collectors provide regular reports of market heads failing to communicate the fee fixing resolution to group members, with tax collectors explaining that this makes their job more difficult by increasing the hostility of traders towards them.

While the overall picture is thus discouraging, there are nevertheless scattered examples of more effective relations between associations and the local government. This includes a small number of associations in both districts that have both negotiated tax rates with the assembly or chief, and collected revenue on behalf of these authorities. For example, the seamstress association in Lawra collects payments on behalf of the local government from its members, and has negotiated down the rate its members pay to the district assembly for business licenses. ${ }^{28}$ In Yendi, the aforementioned market cooperative assists revenue officers in collecting the tax on export foodstuffs, earning a commission for doing so. Meanwhile, more informally, a pito brewers' association in Lawra successfully negotiated with the local chiefs in order to absolve its members of the obligation to contribute informal taxes for the annual Kobine, or harvest, festival when business was slow.

However, even where such bargains have been struck they are best understood as pragmatic ventures, rather than avenues for expanded taxpayer engagement with the local government, as there is no evidence that these forms of 'associational taxation' have led to greater political mobilisation or accountability in other issue areas. Tellingly, the executive secretary of the Lawra Cooperatives Union was not aware of any revenue mobilisation partnerships with associations in the district, despite their existence in practice. For their part, association members do not generally view engagement with the local government as a critical role for associations, which are first and foremost expected to keep trade flowing in the market and to support members in ceremonial and social activities (see also Owusu and Lund 2004; Clark 2010a and 2010b).

25 Personal interviews with Yendi Cooperative Food Farming and Market Society Representative, July 2012, Yendi, Ghana and YMA Councillor (Assembly Member), July 2012, Yendi, Ghana.

26 Personal interview with District Cooperatives Union Secretary, August 2012, Lawra, Ghana.

27 Personal interviews with the Yendi External Auditor, July 2012, Yendi, Ghana and District Cooperatives Union Secretary, August 2012.

28 Members of this association pay GHS4 (Ghanaian New Cedi) quarterly, while seamstresses that are not members of the association must pay GHS6 quarterly. 


\section{Formal rules, informal realities and policy implications}

Confronted with the reality of a local government system of market and small business taxation characterised by weak collection, negotiation of rates, widespread leakages, and ineffective monitoring, calls for reform have become increasingly emphatic. Seen through a technocratic lens, appropriate prescriptions are relatively straightforward, and to some extent already reflected in developments throughout Ghana. These include the creation of new monitoring frameworks and requirements, extending the reach and authority of the national revenue agency, rotation of national staff to avoid collusion between taxpayers and officials, aggressive penalties for noncompliance and an overall drive towards legal rationality.

However, the realities of local government taxation suggest that, taken in isolation, these approaches may frequently have limited success, and may potentially be counterproductive. Improved monitoring is certainly welcome, but the starkly limited revenues available from small traders, and the distances involved in monitoring sub-district areas, virtually ensure that frontline interactions and informal norms will remain pivotal to actual outcomes. There is similarly little evidence to suggest that harsh penalties, the rotation of staff and the extension of the power of the GRA have led to improved collection, but it is clear that they have in many cases served to breed mistrust between taxpayers and the government. Meanwhile, standard reform proposals frequently fail to acknowledge the legitimate equity benefits that may arise from existing informal norms or to recognise the ways in which unequal local power dynamics can distort the intended goals of reform. The implication is not to abandon the drive towards improved monitoring and rules-based taxation, but to identify reform strategies that acknowledge inescapable local constraints, that work 'with the grain' of existing practices and that seek to embrace the benefits that can arise from informality, while curbing the worst excesses of these systems. While this remains an area for further research, evidence from northern Ghana points toward a set of preliminary messages.

\subsection{Engage and strengthen local market associations}

In seeking to strengthen local government tax collection from market sellers and small businesses, three basic facts loom large. First, limited resources mean that the ability of governments to monitor frontline collection is likely to remain limited, with collection correspondingly heavily shaped by informal norms. Second, taxpayers frequently express a willingness to pay more taxes in return for greater transparency and greater reciprocity from government. Third, local governments claim to work with local market associations in order to develop policy, monitor collection and transmit information to taxpayers, but evidence from our research makes clear that either these claims are disingenuous or these efforts are undermined by weak ties between the formal representatives of market associations and the bulk of traders.

Against this background there appears to be a powerful impetus for reformist governments to proactively engage and strengthen local market associations. Most basically, closer engagement with empowered market associations offers an informal mechanism for monitoring tax collection. At one extreme, research has documented the potential for partnering directly with informal associations in collecting revenue from their members (Joshi and Ayee 2008; Joshi et al. forthcoming). However, even less formalised arrangements offer the potential for associations to play an important role in ensuring rules-based collection, while retaining some scope for frontline 
negotiation and flexibility. At least as important, strengthening market associations has the potential to facilitate collective action and bargaining by otherwise vulnerable and isolated traders, which may allow for greater reciprocity and trust between taxpayers and governments. ${ }^{29}$

Consistent with this view, many traders in our case districts emphasised that they would be willing to pay more taxes if collection was more accountable and taxes resulted in tangible improvements in market services and infrastructure. The long history of formal and informal market associations, and of commodity market groups, lends credence to the idea that they have the potential to be effective channels through which taxpayers connect to their local governments. However, a more effective role for market associations will depend on proactive efforts to create space for engagement with local governments, and to press for greater inclusiveness within these associations. As it stands, in Lawra and Yendi, associations often appear to replicate existing inequalities while failing to play the constructive role that is sometimes ascribed to them in existing debates.

\subsection{Engage traditional authorities}

An equally pivotal feature of the account here is the extent to which effective tax collection depends on informal relationships, the support of powerful local brokers and quasi-voluntary tax compliance among rank and file traders. Research elsewhere has increasingly highlighted that in the absence of some degree of legitimacy, improved local government tax collection is likely to remain difficult to achieve (Jibao and Prichard 2014; Ali, Fjeldstad and Sjursen 2013). Pivotal to this relationship in Ghana is the role of the chieftaincy, which has historically been central to tax collection and informally continues to wield significant influence over tax compliance, while also collecting a range of 'informal taxes' (Jönsson 2009; Atuguba 2006; Rathbone 1999; Agyemang 2011). Particularly within sub-district area councils, revenue collectors are largely unable to mobilise revenue from taxpayers without the tacit support of the local chief. ${ }^{30}$

While this authority can be used to support the local government, it can also be used to undermine local government tax collection and legitimacy. Moreover, there are clear risks that the chieftaincy may be unaccountable and may reinforce existing hierarchies and regressive patterns of tax collection. There appears to be a correspondingly strong argument to be made for local governments to engage proactively with the chieftaincy in seeking to gain support for local tax collection, while also advocating for equitable enforcement practices. ${ }^{31}$

\subsection{Empower local government authorities}

Acknowledging the social foundations of local government taxation also argues for empowering local tax authorities, rather than turning to central government tax collectors to strengthen enforcement. The GRA has focused on employing 'outsiders' as local tax collectors as a strategy to reduce the scope for collusion between taxpayers and tax collectors. This is an intuitive

29

Successes of informal trading and occupational associations in achieving greater inclusion within local and even national policy spaces has been reported elsewhere (e.g. Meagher and Lindell 2013; Lindell 2010; Devenish and Skinner 2004; Andrae and Beckman 2013; Kinyanjui 2013; Prag 2013; Meagher 2013). Nevertheless, research also emphasises that marginalised groups may have a limited ability to form effective linkages with the state even when they form highly organised associations (Cleaver et al. 2013; Meager 2013). Recent evidence from Sierra Leone likewise highlights the ability of chiefs to essentially block implementation of the property tax, but also provides evidence of how important perceptions of the chief are to tax compliance (Jibao and Prichard 2013 , 2014).

31 Tentative but somewhat ad hoc efforts in this direction have occurred in Ghana, some of them supported by the German development agency, Deutsche Gesellschaft für Internationale Zusammenarbeit (GIZ). Similar efforts to engage chiefs as allies in tax reform initiatives have been documented in Sierra Leone (Jibao and Prichard 2013). 
strategy, and does appear to yield somewhat stricter enforcement. However, the investigation here, and anecdotal evidence elsewhere, suggests that gains in revenue are likely to be modest, in large part because of the emergence of a more adversarial relationship between external tax collectors and taxpayers.

While the benefits of relying on the national tax authority to collect taxes from small businesses thus appears overstated, experience in Lawra and Yendi speaks clearly to the potential costs of such an approach. Interviews with small taxpayers make clear that they have dramatically better relationships with local tax collectors. This relationship does not appear to reflect the simple absence of enforcement, but the greater flexibility of local tax collectors in responding to the often very real livelihood constraints faced by precarious small traders. There seems a broader likelihood - though one that warrants further research - that this more trusting relationship with tax collectors may have broader implications for perceptions of the legitimacy of the state. The implication is that the technocratic instinct toward strengthening collection through coercion by more autonomous tax collectors may frequently be self-defeating, with any short-term revenue gains more than offset by often overlooked impacts on trust in the state and on the extent and flexibility of the actual tax burden borne by the poor.

\section{Conclusion}

The weakness of local government tax collection in low-income countries is by now well documented, as are a relatively standard set of policy and administrative reforms designed to yield improved outcomes. However, to date, progress in achieving improved outcomes has been slow. These poor outcomes can be traced to a wide variety of sources, including uncommitted local reform leadership, limited resources and a lack of support from central governments. To this story we have sought to add another, more subtle challenge: the need to pay closer attention to the social foundations of tax collection in resource constrained and comparatively marginalised local government areas. We have argued that an acknowledgement of the inescapable resource and capacity constraints facing many local governments, and of the correspondingly critical role of informal practices in shaping outcomes, points towards the need for more contextually appropriate approaches to reform.

Underlying our policy suggestions is a call for greater openness to the potential value of 'hybridity' in the governance of local taxation, particularly among marginalised groups. Such an approach seeks to maximise the benefits that can emerge from reliance on flexible local systems - what Meagher and Lindell (2013) call an 'ethos of "normalisation"' - while minimising the risks that powerful interests will capture such informality and reinforce existing inequalities. The latter point is critical, as informal norms can generate improved governance outcomes, but are only likely to do so consistently, and for the most marginalised, if supported by proactive efforts to reinforce the ability of marginalised groups to participate in shaping these informal practices (Cleaver et al. 2013). Such efforts stand not only to improve the equity of tax outcomes, but also, potentially, to strengthen the ability of marginalised taxpayers to engage in broader bargaining with local governments. 


\section{Appendix}

\section{Interviews}

\begin{tabular}{|c|c|c|c|}
\hline Date & Location & Organisation, Unit & Interviewee position \\
\hline $\begin{array}{l}\text { December } 2011 \text { and } \\
\text { July } 2012\end{array}$ & Yendi & $\begin{array}{l}\text { Yendi Municipal } \\
\text { Assembly (YMA) }\end{array}$ & Accounts Officer \\
\hline July 2012 & Yendi & YMA & Cashier \\
\hline July 2012 & Yendi & YMA & $\begin{array}{l}\text { Deputy Municipal } \\
\text { Finance Officer }\end{array}$ \\
\hline July 2012 & Yendi & YMA & $\begin{array}{l}\text { Municipal Finance } \\
\text { Officer }\end{array}$ \\
\hline $\begin{array}{l}\text { December } 2011 \text { and } \\
\text { July } 2012\end{array}$ & Yendi & $\begin{array}{l}\text { YMA Market } \\
\text { Revenue Office }\end{array}$ & $\begin{array}{l}\text { Chief Superintendent, } \\
\text { Revenue Collection: } \\
\text { Market taxation, } \\
\text { market stall rents, } \\
\text { property rate, } \\
\text { business licenses }\end{array}$ \\
\hline July 2012 & Yendi & $\begin{array}{l}\text { YMA Market } \\
\text { Revenue Officer }\end{array}$ & $\begin{array}{l}\text { Chief Superintendent, } \\
\text { Revenue Collection: } \\
\text { Export foodstuffs }\end{array}$ \\
\hline $\begin{array}{l}\text { December } 2011 \text { and } \\
\text { July } 2012\end{array}$ & Yendi & $\begin{array}{l}\text { Ghana Revenue } \\
\text { Authority (GRA), } \\
\text { Domestic Tax Unit }\end{array}$ & $\begin{array}{l}\text { District Tax Inspector } \\
\text { Manager }\end{array}$ \\
\hline $\begin{array}{l}\text { December } 2011 \text { and } \\
\text { July } 2012\end{array}$ & Yendi & $\begin{array}{l}\text { GRA, Domestic Tax } \\
\text { Unit }\end{array}$ & $\begin{array}{l}\text { District Revenue } \\
\text { Collector }\end{array}$ \\
\hline $\begin{array}{l}\text { December } 2011 \text { and } \\
\text { July } 2012\end{array}$ & Yendi & $\begin{array}{l}\text { GRA, Domestic Tax } \\
\text { Unit }\end{array}$ & $\begin{array}{l}\text { District Revenue } \\
\text { Collector }\end{array}$ \\
\hline December 2011 & Yendi & $\begin{array}{l}\text { GRA, Domestic Tax } \\
\text { Unit }\end{array}$ & $\begin{array}{l}\text { District Chief } \\
\text { Revenue Collector }\end{array}$ \\
\hline December 2011 & Yendi & $\begin{array}{l}\text { GRA, Domestic Tax } \\
\text { Unit }\end{array}$ & $\begin{array}{l}\text { District Revenue } \\
\text { Collector }\end{array}$ \\
\hline July 2012 & Yendi & YMA & $\begin{array}{l}\text { Assembly Member } \\
\text { (Councillor) }\end{array}$ \\
\hline July 2012 & Yendi & $\begin{array}{l}\text { Yendi Cooperative } \\
\text { Food Farming and } \\
\text { Market Society }\end{array}$ & Representative \\
\hline July 2012 & Yendi & $\begin{array}{l}\text { External Audit } \\
\text { Service of Ghana }\end{array}$ & District Auditor \\
\hline July 2012 & Yendi & $\begin{array}{l}\text { Lands Commission } \\
\text { Office }\end{array}$ & $\begin{array}{l}\text { Land Valuation } \\
\text { Division Director }\end{array}$ \\
\hline August 2012 & Lawra & $\begin{array}{l}\text { Lawra District } \\
\text { Assembly (LDA) }\end{array}$ & $\begin{array}{l}\text { District Coordinating } \\
\text { Director }\end{array}$ \\
\hline $\begin{array}{l}\text { December } 2011 \text { and } \\
\text { August } 2012\end{array}$ & Lawra & LDA & Internal Auditor \\
\hline $\begin{array}{l}\text { December } 2011 \text { and } \\
\text { August } 2012\end{array}$ & Lawra & LDA & $\begin{array}{l}\text { District Finance } \\
\text { Officer }\end{array}$ \\
\hline $\begin{array}{l}\text { December } 2011 \text { and } \\
\text { August } 2012\end{array}$ & Lawra & LDA & $\begin{array}{l}\text { District Budget } \\
\text { Officer }\end{array}$ \\
\hline
\end{tabular}




\begin{tabular}{|c|c|c|c|}
\hline $\begin{array}{l}\text { December } 2011 \text { and } \\
\text { August } 2012\end{array}$ & Lawra & LDA & Chief Cashier \\
\hline August 2012 & Lawra & LDA & $\begin{array}{l}\text { Assembly member, } \\
\text { Sub-Committee for } \\
\text { Finance and } \\
\text { Administration } \\
\text { member }\end{array}$ \\
\hline December 2011 & Lawra & $\begin{array}{l}\text { National Commission } \\
\text { for Civic Education }\end{array}$ & District Field Officer \\
\hline August 2012 & Lawra & $\begin{array}{l}\text { District Cooperatives } \\
\text { Union }\end{array}$ & Secretary \\
\hline August 2012 & Lawra & $\begin{array}{l}\text { Lands Commission } \\
\text { Office, Town and } \\
\text { Country Planning, } \\
\text { Survey and Mapping } \\
\text { Division }\end{array}$ & District Officer \\
\hline August 2012 & Lawra & $\begin{array}{l}\text { National Youth } \\
\text { Assembly }\end{array}$ & $\begin{array}{l}\text { District Vice- } \\
\text { President }\end{array}$ \\
\hline December 2011 & Lawra & $\begin{array}{l}\text { GRA Domestic Tax } \\
\text { Revenue Unit }\end{array}$ & $\begin{array}{l}\text { Regional Statistician, } \\
\text { Upper West }\end{array}$ \\
\hline August 2012 & Lawra & Lawra Town Council & Secretary \\
\hline August 2012 & Lawra & $\begin{array}{l}\text { Lawra sub-district } \\
\text { council }\end{array}$ & $\begin{array}{l}\text { Revenue Collection } \\
\text { Supervisor }\end{array}$ \\
\hline December 2011 & Lawra & Lawra Town Council & $\begin{array}{l}\text { Chief Market } \\
\text { Revenue Collector }\end{array}$ \\
\hline August 2012 & Lawra & $\begin{array}{l}\text { Lawra District } \\
\text { Cooperatives Union }\end{array}$ & Secretary \\
\hline July 2012 & Accra & $\begin{array}{l}\text { Local Government } \\
\text { Service Secretariat } \\
\text { (LGSS), Local } \\
\text { Service Delivery and } \\
\text { Governance } \\
\text { Programme }\end{array}$ & $\begin{array}{l}\text { Director, Quality } \\
\text { Assurance and } \\
\text { Technical and } \\
\text { National Coordinator, } \\
\text { National Programme } \\
\text { Secretariat }\end{array}$ \\
\hline July 2012 & Accra & $\begin{array}{l}\text { LGSS, Local Service } \\
\text { Delivery and } \\
\text { Governance } \\
\text { Programme }\end{array}$ & Technical Advisor \\
\hline July 2012 & Accra & LGSS & $\begin{array}{l}\text { Director, Financial } \\
\text { Management }\end{array}$ \\
\hline July 2012 & Accra & LGSS & $\begin{array}{l}\text { Director, Policy, } \\
\text { Planning, Budgeting, } \\
\text { Monitoring and } \\
\text { Evaluation }\end{array}$ \\
\hline July 2012 & Accra & LGSS & Development Planner \\
\hline July 2012 & Accra & $\begin{array}{l}\text { Ministry of Local } \\
\text { Government and } \\
\text { Rural Development } \\
\text { (MLGRD) }\end{array}$ & $\begin{array}{l}\text { Planning and Budget } \\
\text { Officer }\end{array}$ \\
\hline
\end{tabular}




\begin{tabular}{|c|c|c|c|}
\hline July 2012 & Accra & $\begin{array}{l}\text { Ministry of Finance } \\
\text { and Economic } \\
\text { Planning }\end{array}$ & $\begin{array}{l}\text { Director, Fiscal } \\
\text { Decentralisation }\end{array}$ \\
\hline July 2012 & Accra & $\begin{array}{l}\text { Deutsche } \\
\text { Gesellschaft für } \\
\text { Internationale } \\
\text { Zusammenarbeit } \\
\text { (GIZ), Good Financial } \\
\text { Governance } \\
\text { Programme }\end{array}$ & Senior Tax Advisor \\
\hline November 2011 & Accra & $\begin{array}{l}\text { GIZ within Ministry of } \\
\text { Finance and } \\
\text { Economic Planning }\end{array}$ & Senior Tax Advisor \\
\hline July 2012 & Accra & $\begin{array}{l}\text { GIZ, Support for } \\
\text { Decentralisation } \\
\text { Reform Programme }\end{array}$ & Senior Advisor \\
\hline July 2012 & Accra & $\begin{array}{l}\text { GIZ, Support for } \\
\text { Decentralisation } \\
\text { Reform Programme }\end{array}$ & Programme Officer \\
\hline July 2012 & Accra & $\begin{array}{l}\text { USAID, Local } \\
\text { Governance and } \\
\text { Decentralisation } \\
\text { Programme }\end{array}$ & Consultant \\
\hline $\begin{array}{l}\text { November and } \\
\text { December 2011, July } \\
2012\end{array}$ & Accra & Christian Aid Ghana & Country Manager \\
\hline $\begin{array}{l}\text { November and } \\
\text { December 2011, July } \\
2012\end{array}$ & Accra & Christian Aid Ghana & Programme Officer \\
\hline November 2011 & Accra & $\begin{array}{l}\text { Ghana Integrity } \\
\text { Initiative }\end{array}$ & Programme Manager \\
\hline July 2012 & Accra & $\begin{array}{l}\text { Institute of Local } \\
\text { Government Studies }\end{array}$ & $\begin{array}{l}\text { Dean, Research and } \\
\text { Studies }\end{array}$ \\
\hline November 2011 & Accra & $\begin{array}{l}\text { Ghana Association of } \\
\text { Women } \\
\text { Entrepreneurs } \\
\text { (GAWE) }\end{array}$ & President \\
\hline December 2011 & Wa, Upper West & GAWE & $\begin{array}{l}\text { Member, small } \\
\text { business owner }\end{array}$ \\
\hline December 2011 & Wa, Upper West & GAWE & $\begin{array}{l}\text { Member, small } \\
\text { business owner }\end{array}$ \\
\hline December 2011 & Wa, Upper West & GAWE & $\begin{array}{l}\text { Member, small } \\
\text { business owner }\end{array}$ \\
\hline December 2011 & Wa, Upper West & SEND Ghana (NGO) & Programme Officer \\
\hline
\end{tabular}




\section{References}

Agyemang, Y. S. (2011) 'Crisis of Legitimacy: Secularisation and the Authority of Asante Traditional Rulers in Ghana's Decentralization', Perspectives on Global Development and Technology 10: 300-326

Ali, M., Fjeldstad, O-H. and Sjursen, I. (2013) To Pay or Not to Pay? Citizens' Attitudes towards Taxation in Kenya, Tanzania, Uganda and South Africa. Afrobarometer Working Paper 143

Andrae, G. and Beckman, B. (2013) 'Lagos Tailors, Trade Unions, and Organizations in the Informal Economy', African Studies Review 56 (3): 191-208

Atuguba, R. (2006) The Tax Culture of Ghana: A Research Report Prepared for the Revenue Mobilisation Support, Accra: GTZ Revenue Mobilisation Support Ghana

Bahiigwa, G., Ellis, F., Fjeldstad, O-H. and Iversen, V. (2004) Rural Taxation in Uganda: Implications for Growth, Income Distribution, Local Government Revenue and Poverty Reduction. EPRC Research Series Number 35, Kampala: Economic Policy Research Center

Bahl, R. (1999) 'Fiscal Decentralization as Development Policy', Public Budgeting and Finance $19(2): 59-75$

Bahl, R. and Bird, R. (2008) 'Subnational Taxes in Developing Countries: the Way Forward', Public Budgeting and Finance 28 (4): 1-25

Bird, R. (2011) 'Subnational Taxation in Developing Countries: A Review of the Literature', Journal of International Commerce, Economics and Policy 2 (1): 1-23

Bird, R. M., and Zolt, E. M. (2005) 'The Limited Role of the Personal Income Tax in Developing Countries', Journal of Asian Economics 16: 928-46

Blundo, G. 2006. 'Dealing with the local state: the informal privatization of street-level bureaucracies in Senegal', Development and Change 37 (4): 799-819

Booth, D. (2011a) 'Working with the Grain? The Africa Power and Politics Programme', IDS Bulletin 42 (2): 1-10

_ (2011b) 'Towards a Theory of Local Governance and Public Goods Provision', IDS Bulletin 42 (2): 11-21

Burki, S. J., Perry, G. and Dillinger, W. (1999) Beyond the Center: Decentralizing the State, Washington, D.C.: The World Bank

Cantens, T. (2012) Informal Trade Practices. WCO Research Paper No. 22, Brussels: World Customs Organization

Carroll, E. (2011) Taxing Ghana's Informal Sector: The Experience of Women. Christian Aid Occasional Paper, Accra: Christian Aid Ghana 
Centre for the Future State (2010) An Upside Down View of Governance, Brighton: IDS

Clark, G. (2010a) 'Gender Fictions and Gender Tensions Involving 'Traditional' Asante Market Women', African Studies Quarterly 11 (2 \& 3): 43-66

(2010b) Onions Are My Husband: Survival and Accumulation by West African Market Women, Chicago: Chicago University Press

(2004) 'Managing Transitions and Continuities in Ghanaian Trading Contexts', African Economic History 32: 65-88

(2002) 'Market Association Leaders' Strategic Use of Language and Narrative in Market Disputes and Negotiations in Kumasi, Ghana', Africa Today 49 (1): 43-58

(1991) 'Colleagues and Customers in Unstable Market Conditions: Kumasi, Ghana', Ethnology 30 (1): 31-48

Cleaver, F. (2001) 'Institutional Bricolage, Conflict and Cooperation in Usangu, Tanzania,' IDS Bulletin 32 (4): 26-35

Cleaver, F., Franks, T., Maganga, F., and Hall, K. (2013) 'Institutions, Security, and Pastoralism: Exploring the Limits of Hybridity', African Studies Review 56 (3): 165-89

Crook, R. (2003) Decentralisation and Poverty Reduction in Africa: The politics of local-central relations. Public Administration and Development 23 (1): 77-88

Crook, R. and Manor, J. (1998) Democracy and Decentralisation in South Asia and West Africa: Participation, Accountability and Performance, Cambridge: Cambridge University Press

Crook, R. and Sverrisson, A. (2003) 'Does Decentralization Contribute to Poverty Reduction? Surveying the Evidence', in P. Houtzager and M. Moore (eds) Changing Paths: International Development and the New Politics of Inclusion. Ann Arbor: University of Michigan Press

Cummings, R., Martinez-Vazquez, J., McKee, M. and Torgler, B. (2005) Effects of Tax Morale on Tax Compliance: Experimental and Survey Evidence. CREMA Working Paper Series 2005-29, Center for Research in Economics, Management and the Arts (CREMA)

Devarajan, S., Khemani, S. and Shah, S. (2009) 'The politics of partial decentralization', in E. Ahmad and G. Brosio (eds) Does Decentralization Enhance Service Delivery and Poverty Reduction? Cheltenham, UK: Edward Elgar, pp. 102-124

Devenish, A., and Skinner, C. (2004) Organising Workers in the Informal Economy: The Experience of the Self Employed Women's Union, 1994-2004, South Africa: School of Development Studies, University of KwaZulu-Natal

Fjeldstad, O-H. (2004) 'What's Trust Got To Do With It? Non-Payment of Service Charges in Local Authorities in South Africa', Journal of Modern African Studies 42 (4): 539-62 
Fjeldstad, O-H. and Semboja, J. (2001) 'Why People Pay Taxes: The Case of the Development Levy in Tanzania', World Development 29 (12): 2059-74

Flynn, D. (1997) 'We are the Border': Identity, Exchange, and the State along the Benin-Nigeria Border, American Anthropologist 24 (2): 311-330

Government of Ghana (GoG) (1992) Fourth Republican Constitution, Accra: GOG

Gouldner, Alvin W. (1960) 'The Norm of Reciprocity: A Preliminary Statement', American Sociological Review 25 (2): 161-178

Grindle, M. S. (2002) Good Enough Governance: Poverty Reduction and Reform in Developing Countries, Boston: Harvard University

Guha-Khasnobis, B., Kanbur, R. and Ostrom, E. (eds) (2006) Linking the Formal and Informal Economy: Concepts and Policies, Oxford: Oxford University Press

Jibao, S. and Prichard, W. (2014) Tax Perceptions in the Periphery: The Local Foundations of Tax Compliance in District Councils in Sierra Leone, mimeo

(2013) Rebuilding Local Government Finances After Conflict: The Political Economy of Property Taxation in Post-Conflict Sierra Leone', ICTD Working Paper 12, Brighton: IDS

Jönsson, J. (2009) 'The overwhelming minority: inter-ethnic conflict in Ghana's northern region', Journal of International Development 21: 507-519

Joshi, A. and Ayee, J. (2008) 'Associational Taxation: A pathway into the informal sector', in D. Bräutigam, O-H. Fjeldstad, and M. Moore (eds) Taxation and State Building in Developing Countries: Capacity and Consent, Cambridge: Cambridge University Press, pp. 183-211

Joshi, A., and Moore, M. (2004) 'Institutionalized Co-Production: Unorthodox Public Service Delivery in Challenging Environment', Journal of Development Studies 40 (4): 31-49

Joshi, A., Prichard, W. and Heady, C. (forthcoming) 'Taxing the Informal Economy: Challenges, Possibilities and Remaining Questions', Journal of Development Studies

Juul, C. (2006) 'Decentralization, Local Taxation and Citizenship in Senegal', Development and Change 37 (4): 821-46

Kelsall, T. (2011) 'Going with the Grain in African Development?' Development Policy Review 29 (51): 5223-5251

Kinyanjui, M. N. (2013) 'Women Informal Garment Traders in Taveta Road, Nairobi: From the Margins to the Center', African Studies Review 56 (3): 147-64

Ladouceur, P. A. (1979) Chiefs and Politicians: The Politics of Regionalism in Northern Ghana, London: Longman

Lawra District Assembly (LDA) (2009) Fee Fixing Resolution (1st Jan-31st Dec 2009), Lawra: LDA 
Levi, M. (1988) Of Rule and Revenue, Berkeley: University of California Press

Lindell, I. (2010) 'Between Exit Voice: Informality and the Spaces for Popular Agency', African Studies Quarterly 11: 1-11

Meagher, K. (2013) 'Informality, Religious Conflict, and Governance in Northern Nigeria:

Economic Inclusion in Divided Societies', African Studies Review 56 (3): 209-34

(2010) Identity Economics: Social Networks and the Informal Economy in Nigeria, Suffolk: James Currey

- and Lindell, I. (2013) 'Introduction: Engaging with African Informal Economies: Social Inclusion or Adverse Incorporation', African Studies Review 56 (3): 57-76

Moore, M. (2013) Obstacles to Increasing Tax Revenues in Low Income Countries. ICTD Working Paper 15, Brighton, UK: ICTD.

Olivier de Sardan, J-P. (2008) Researching the practical norms of real governance in Africa. Discussion paper No. 5, Africa Power and Politics Research Programme, London: Overseas Development Institute

(1999) 'A moral economy of corruption in Africa?' The Journal of Modern African Studies $37(1): 25-52$

Olken, B. A., and Singhal, M. (2011) 'Informal Taxation', American Economic Journal: Applied Economics 3: 1-28

Owusu, G. and Lund, R. (2004) 'Markets and Women's Trade: Exploring their Role in District Development in Ghana', Norwegian Journal of Geography 58 (3): 113-124

Prag, E. (2013) 'Mama Benz in Trouble: Networks, the State, and Fashion Wars in the Beninese Textile Market', African Studies Review 56 (3): 101-21

Prichard, W. (2010) Taxation and State Building: Towards a Governance Focused Tax Reform Agenda. IDS Working Paper Number 341, Brighton, UK: University of Sussex

Rathbone, R. (1999) Nkrumah and the Chiefs: The Politics of Chieftaincy in Ghana, 1951- 1960, Oxford: James Currey

Roitman, J. (2005) Fiscal Disobedience. An Anthropology of Economic Regulation in Central Africa, Princeton: Princeton University Press

Schomerus, M. and Titeca, K. (2012) 'Deals and Dealings: Inconclusive Peace and Treacherous Trade along the South Sudan-Uganda Border', Africa Spectrum 47 (2-3): 5-31

Scott, J. C. (1976) The Moral Economy of the Peasant: Rebellion and Subsistence in Southeast Asia, New Haven: Yale University Press

Smoke, P. (2013) Why Theory and Practice are Different: The Gap between Principles and Reality in Subnational Revenue Systems. International Center for Public Policy Working Paper 13 
Smoke, P. and Lewis, B. D. (1996) 'Fiscal Decentralization in Indonesia: A New Approach to an Old Idea', World Development 24 (8): 1281-1299

Tait, D. (1961) The Konkomba of Northern Ghana, London: Oxford University Press

Tegera, A. and Johnson, D. (2007) Rules for Sale: Formal and Informal Cross-border Trade in $D R C$. A Pole Institute Report, Goma: Pole Institute

Thompson, E.P. (1971) 'The Moral Economy of the English Crowd during the Eighteenth Century', Past \& Present 50: 76-117

Tilly, C. (2005) 'Regimes and Contention', in T. Janoski (ed) The Handbook of Political Sociology: States, Civil Societies, and Globalization, Cambridge: Cambridge University Press

Titeca, K. (2011). 'Access to Resources and Predictability in Armed Rebellion: The FAPC's Short-Lived 'Monaco' in Eastern Congo', African Spectrum 46(2): 43-70.

Titeca K. and De Herdt T. (2010) 'Regulation, Cross-border Trade and Practical Norms in WestNile, North-Western Uganda', Africa 80 (4): 573-594

Titeca, K. and Flynn, R. (2014) '"Hybrid Governance," Legitimacy, and (II)legality in the Informal Cross-Border Trade in Panyimur, Northwest Uganda', African Studies Review 57(1): 71-91

Titeca, K. with Kimanuka, C. (2012) Walking in the Dark: Informal Cross-Border Trade in the Great Lakes Region, London: International Alert

Torgler, B. (2005) 'Tax Morale in Latin America', Public Choice, No. 122: 133-57

World Bank (2011) Facilitating Cross-Border Trade Between the DRC and Neighbours in the Great Lakes Region of Africa: Improving Conditions for Poor Traders, Washington, DC: World Bank (2004) Bridging the North South Divide in Ghana, Washington, D.C.: World Bank 


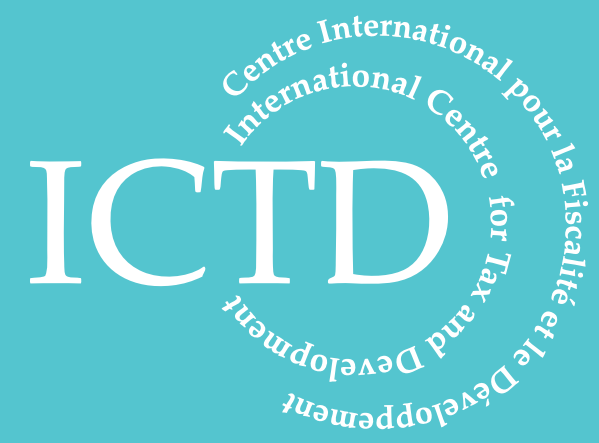

International Centre for Tax and Development at the Institute of Development Studies

Brighton BN1 9RE, UK

T: +44 (0) 1273606261

F: $+44(0) 1273621202$

E: info@ictd.ac

www.ictd.ac 